\title{
Microbiological and epidemiological study of infectious keratitis in children and adolescents
}

\author{
Estudo microbiológico e epidemiológico da ceratite infecciosa em crianças e adolescentes
}

Maria Cecilia Zorat Yuㄹ, Ana luisa Höfling-Lima ${ }^{1}$, Guilherme Henrique Campos Furtado²

\begin{abstract}
Purpose: To analyze epidemiological and microbiological aspects of microbia keratitis in children and adolescents.

Methods: This retrospective cohort study was conducted at the Department of Ophthalmology and Visual Science, Escola Paulista de Medicina, Universidade Federal de São Paulo, between July 15, 1975, and December 31, 2010. We analyzed corneal samples from 859 patients with clinical suspicion of infectious keratitis, comparing epidemiological and microbiological characteristics of bacterial keratitis with those of non-bacterial and non-viral keratitis. We also compared Gram-positive and Gram-negative pathogens in patients with bacterial keratitis. We created a susceptibility profile of the bacterial microorganisms studied.

Results: Of the 859 patients, 346 (40.3\%) showed positive culture results for non-viral microorganisms. Teenagers (13-18 years) made up the group with the highest number of patients with keratitis $(164,47.4 \%)$. The most frequent risk factors for keratitis were trauma (33.5\%) and previous ocular surgery (24.9\%). Gram-positive bacteria (71.8\%) were the most often isolated, with coagulase-negative Staphylococcus (23.8\%) the most prevalent microorganism. Logistic regression analysis showed age $(p=0.002)$, topical antimicrobial drug use $(p=0.01)$, and trauma due to non-chemical burns ( $p=0.005$ ) were risk factors for non-bacterial keratitis. Age ( $p=0.01$ ) was also a risk factor for Gram-negative bacterial keratitis.

Conclusion: Our study showed that in the age range studied, the prevalence of keratitis caused by Gram-negative bacteria or by the non-viral microorganisms evaluated increases with age. Previous use of topical antimicrobial drug and trauma due to non-chemical burns are associated with non-bacterial keratitis. Knowledge of the risk factors and the microorganisms involved may help improve treatment of keratitis in children and adolescents and minimize visual impairment.
\end{abstract}

Keywords: Keratitis/microbiology; Keratitis/epidemiology; Eye infections; Children; Adolescent

\section{RESUMO}

Objetivos: Descrever o perfil epidemiológico e microbiológico de ceratite microbiana em crianças e adolescentes.

Métodos: Estudo retrospectivo tipo coorte, utilizando fichas laboratoriais de pacientes, atendidos no Departamento de Oftalmologia e Ciências Visuais - Escola Paulista de Medicina - Universidade Federal de São Paulo, entre 15 de julho de 1975 a 31 de dezembro de 2010. Foram comparados pacientes com ceratite bacteriana e não bacteriana (não viral). Entre os pacientes com ceratite bacteriana, foram comparados aqueles em que a ceratite foi causada por bactérias Gram positivas e Gram negativas. O perfil de sensibilidade dos microrganismos bacterianos aos antimicrobianos também foi estudado.

Resultados: Foram analisadas amostras corneanas de 859 pacientes com suspeita clínica de ceratite infecciosa, na faixa etária estudada. Destes, 346 (40,3\%) apresentaram resultados de culturas positivas para microrganismos não virais. Adolescentes (13 a 18 anos) compuseram o grupo com maior número de pacientes com ceratite (164-47,4\%). Os principais fatores de risco foram trauma $(33,5 \%)$ e cirurgias oculares prévias $(24,9 \%)$. Bactérias Gram positivas foram isoladas com maior frequência (71,8\%), sendo prevalente o patógeno Staphylococcus coagulasenegativo (23,8\%). De acordo com a análise de regressão logística, idade $(p=0,002)$, uso tópico de drogas antimicrobianas $(p=0,01)$ e trauma por queimadura não química $(p=0,005)$ foram fatores predisponentes para ceratite não bacteriana. I dade $(p=0,01)$ também foi fator de risco para ceratite causada por bactérias Gram negativas.

Conclusões: Nosso estudo mostrou que quanto maior a idade, na faixa etária estudada, maior a probabilidade da ceratite ser causada por bactérias Gram negativas elou por outros microrganismos não virais avaliados. O uso tópico de drogas antimicrobianas prévias e trauma devido à queimadura não química predispõe à ceratite não bacteriana. O conhecimento dos fatores de risco e dos microrganismos envolvidos resultarão em tratamento específico da ceratiteem crianças eadolescentes, com menores danos visuais.

Descritores: Ceratite/microbiologia; Ceratite/epidemiologia; Infecçôes oculares; Criança; Adolescente

\section{INTRODUCTION}

Infectious keratitis is rare but potentially serious disease found mainly in young people. It is a preventable cause of visual impairment, similar to including amblyopia in children and mono-or bilateral blindness ${ }^{(1-3)}$.

More than one-third of eye injuries among children and adolescents result from their natural curiosity, immature motor skills, and tendency to imitate adult behavior without assessing the risks relevant to their actions. Although infectious keratitis is not common in this age group, it is potentially devastating as approximately, considering thet $30 \%$ of young victims of serious eye injuries end up with visual acuity lower than $20 / 200^{(4-7)}$. Infectious keratitis are more prevalent in tropical developing countries with poor healthcare systems than in developed countries ${ }^{(3,8-21)}$.

The diagnosis of keratitis is usually clinical and the treatment is empirical, with the application of broad-spectrum topical antimicrobial agents until identification of the etiologic agent is completed. However, few studies have investigated the causative agents and risk factors of infectious keratitis in children and adolescents.

The purpose of this study was to investigate the epidemiological and microbiological findings of infectious keratitis in patients up to 18 years of age attending a tertiary referral center. In addition, the 
risk factors associated with the presence of bacterial keratitis and non-bacterial non-viral keratitis were analyzed, as well as the in vitro susceptibility profile of the bacterial isolates.

\section{METHODS}

This retrospective cohort study assessed microbial keratitis in patients up to 18 years old in the period from July 15,1975 , to December 31,2010 . All data included in the laboratory records of patients with clinical suspicion of keratitis were evaluated at the Ocular Microbiology Laboratory, Department of Ophthalmology, Federal University of São Paulo, São Paulo, Brazil. The variables studied included age, sex, affected eye, use of contact lenses, use of topical medications, ocular antecedents, comorbidities, and previous ocular surgery. The in vitro susceptibility profiles of the bacteria were identified, and the annual incidence of infectious keratitis and the prevalence of etiologic agents were also evaluated. The local Ethics Committee approved this study.

All subjects underwent sample collection from corneal ulcers by an ophthalmologist. The corneal scraping was performed using topical anesthesia with proxymetacaine $(5 \mathrm{mg} / \mathrm{ml})$ or, when necessary, narcosis in the operating room. We inoculated the collected material in solid (blood agar, chocolate agar and Sabouraud agar; Oxoid Ltd., Basingstoke, UK) and liquid (brain heart infusion and thioglycolate; Oxoid Ltd.) culture media ${ }^{(22-24)}$. The material was placed in a transport medium containing saline and sterile distilled water and was subsequently inoculated on plates with soy agar culture media (semi-defined), supplemented with $20 \mu$ l of inactivated Escherichia coli when an infection with the protozoan Acanthamoeba spp. was suspected ${ }^{(24)}$. In our laboratory, the routine practice of this specific culture began in 1987 with the identification and subsequent publication of the first cases of keratitis caused by Acanthamoeba spp. in Brazil (25). Maintenance of the inoculated culture media, and isolation and identification of bacteria, fungi, and the protozoan Acanthamoeba spp. were performed according to standard microbiology procedures (22-24,26). $^{2}$

The assessment of bacterial susceptibility to antimicrobial agents commonly used in ophthalmology was performed by using the Kirby-Bauer agar-diffusion test according to the guidelines of the National Committee for Clinical Laboratory Standards (NCCLS; Philadelphia, PA, USA) until 2004, and, subsequently, by the Clinical and Laboratory Standards Institute (CLSI; Philadelphia, PA, USA).

Categorical variables were analyzed using the chi-square test. Continuous variables were analyzed using Student's t test. A p value $<0.1$ was considered significant. Logistic regression was used with a p value $<0.05$ considered significant. MedCalc software version 11.6.1 $1^{(27)}$ (MedCalc, Ostend, Belgium) was used for the statistical analysis.

\section{RESULTS}

Between July 1975 and December 2010, a total of 859 patients with clinical suspicion of keratitis aged 0-18 years were assessed. From these patients, 346 eyes from 346 patients [197 (56.9\%) boys] with positive cultures for bacteria, fungi and/or the protozoan Acanthamoeba spp. were included in the study.

The right eye was more commonly affected, in 184 (53.2\%) of patients. The age ranged from 10 days to 18 years with a mean of 12 \pm 4.7 years. We divided the patients according to age: there were 5 (1.4\%) newborns (0-28 days), 47 (13.6\%) infants (29 days to 2 years), 57 (16.5\%) pre-school age children (3-6years), 73 (21.1\%) school children (7-12 years), and 164 (47.4\%) adolescents (13-18years). Thus, the most prevalent age group was the adolescents.

Topical medication was used at the time of sample collection in $42.8 \%$ of the patients. Antimicrobial drugs accounted for $71.6 \%$ of the topical medications used (Table 1). Major antecedents included trauma in $33.5 \%$ of patients, previous eye surgery in $24.9 \%$, and the use of contact lenses in $18.2 \%$ (Table 1). Cancer was the major comorbidity found, in seven of the patients, accounting for $2 \%$ of the study patients.

Bacterial cultures were requested for all 346 patients and 309 (89.3\%) tested positive. There were 317 requests for fungal cultures, with $14(4.4 \%)$ testing positive and 97 requests for the protozoan
Acanthamoeba spp. with 23 (23.7\%) of these patients testing positive. Overall, $4 \%$ and $6.6 \%$ of all patients tested positive for fungi and Acanthamoeba spp., respectively.

A total of 344 microorganisms were isolated from the 309 positive bacterial cultures (71.8\% Gram-positive and 28.2\% Gram-negative). The most prevalent bacteria were coagulase-negative Staphylococcus (23.8\%), Staphylococcus aureus (20.9\%), and Pseudomonas spp. (14.2\%) (Table 2). Polymicrobial cultures accounted for $9.5 \%$ of the positive cultures.

Table 1. Frequency of ocular antecedents among patients aged from 10 days to 18 years with keratitis

\begin{tabular}{ll}
\hline Eye history & Total (\%) \\
\hline Ocular antecedent & $148(42.8)$ \\
Use of topical medications & $116(33.5)$ \\
Trauma & $86(24.9)$ \\
Prior eye surgery & $63(18.2)$ \\
Use of contact lenses & $24(6.9)$ \\
Conjunctivitis & $20(5.8)$ \\
Comorbidities & $13(3.8)$ \\
Congenital glaucoma & $11(3.2)$ \\
Keratitis & $8(2.3)$ \\
Keratoconus & $7(2.0)$ \\
Herpes & $3(0.9)$ \\
Atopy & $3(0.9)$ \\
Blepharitis & $2(0.6)$ \\
Endophthalmitis & $2(0.6)$ \\
Stye & $2(0.6)$ \\
Proptosis & $1(0.3)$ \\
Nodular degeneration Salzmann & $1(0.3)$ \\
Entropion & $1(0.3)$ \\
Microphthalmos & $1(0.3)$ \\
Trachoma &
\end{tabular}

Table 2. Prevalence of bacteria isolated from keratitis samples among patients aged from 10 days to 18 years

\begin{tabular}{ll}
\hline Bacteria & Total (\%) \\
\hline Coagulase-negative Staphylococcus & $82(23.8)$ \\
Staphylococcus aureus & $72(20.9)$ \\
Pseudomonas spp. & $49(14.2)$ \\
Streptococcus pneumonia & $31(9.0)$ \\
Streptococcus viridans & $28(8.1)$ \\
Corynebacterium spp. & $21(6.1)$ \\
Moraxella spp. & $16(4.6)$ \\
Serratia spp. & $10(2.9)$ \\
Haemophilus spp. & $8(2.3)$ \\
Streptococcus spp.* & $8(2.3)$ \\
Unidentified Gram- bacilli & $3(0.9)$ \\
Unidentified Gram+ bacilli & $3(0.9)$ \\
Enterobacter spp. & $3(0.9)$ \\
Proteus spp. & $3(0.9)$ \\
Klebsiella spp. & $2(0.6)$ \\
Acinetobacter spp & $1(0.3)$ \\
Bacillus circulans & $1(0.3)$ \\
Citrobacter spp & $1(0.3)$ \\
Neisseria spp & $1(0.3)$ \\
Nocardia asteroides & $1(0.3)$ \\
\hline Total & $\mathbf{3 4 4}$ \\
\hline
\end{tabular}

Tota

344

*= Streptococcus spp.: gamma-hemolytic (4), spp. (3) and beta-hemolytic (1). 
Thirteen filamentous fungi and one yeast, Rhodotorula rubra, were identified. Filamentous fungi included Fusarium solani species complex (64.3\%), Aspergillus flavus species complex, Scedosporium apiospermum, Penicillium spp. (7.1\% each) and one unidentified.

All of the Gram-positive cocci were vancomycin-susceptible. Methicillin-susceptible Staphylococcus showed resistance lower than $10 \%$ to first generation cephalosporins, aminoglycosides, and fluoroquinolones, and resistance lower than 20\% to trimethoprim-sulfamethoxazole. Methicillin-resistant Staphylococcus showed significant resistance to most antimicrobials apart from the most recent generations of fluoroquinolones. Streptococcus pneumoniae showed no resistance to penicillin

Enterobacteriaceae showed full susceptibility to amikacin, ceftriaxone, ciprofloxacin, chloramphenicol, gentamicin, moxifloxacin, and ofloxacin, whereas tobramycin and trimethoprim-sulfamethoxazole showed $5.6 \%$ and $12.5 \%$ resistance, respectively. Pseudomonas aeruginosa showed $100 \%$ susceptibility to amikacin, ciprofloxacin, and oflo- xacin and resistance lower than $6 \%$ to gentamicin, tobramycin, and polymyxin B.

We analyzed the annual incidence of cases of keratitis in children and adolescents and the respective identification of microorganisms over the study period. The percentage of fungal infections remained stable throughout the study period, with positivity ranging from $1.8 \%$ to $16.6 \%$. The prevalence of infections with Acanthamoeba spp. ranged from $1.8 \%$ to $11.1 \%$. Bacterial infections were always the most common, with the prevalence in cultures ranging from 10\% to 100\%.

Univariate analysis comparing patients with bacterial and non-bacterial keratitis showed the following significant variables for non-bacterial keratitis: age $(p=0.001)$, the use of antimicrobial drugs $(p=0.02)$, and non-chemical or physical burns $(p=0.004)$. In the multivariate analysis, age (odds ratio [OR] 1.19; 95\% confidence interval [C] I 1.09-1.31), use of antimicrobial drugs (OR 2.50; $95 \% \mathrm{Cl} 1.19-5.23)$, and physical burn injuries (OR 17.29; 95\%Cl 2.40-124.57) were associated with non-bacterial keratitis (fungal or Acanthamoeba spp.) (Table 3).

Table 3. Univariate and multivariate analyses comparing bacterial versus non-bacterial keratitis among patients aged from 10 days to 18 years

\begin{tabular}{|c|c|c|c|c|c|c|}
\hline & $\begin{array}{l}\text { Bacterial keratitis } \\
(\mathrm{N}=309)\end{array}$ & $\begin{array}{c}\text { Non-bacterial keratitis } \\
(\mathrm{N}=37)\end{array}$ & p-value & Odds ratio & $95 \% \mathrm{Cl}$ & p-value \\
\hline \multicolumn{7}{|l|}{ Variables } \\
\hline Age, years & $10.0 \pm 6.0$ & $14.6 \pm 3.4$ & 0.001 & 1.19 & $1.09-1.31$ & 0.0002 \\
\hline Male sex & $179(57.9)$ & $18(48.6)$ & 0.370 & & & \\
\hline Affected right eye & $166(53.7)$ & $18(48.6)$ & 0.680 & & & \\
\hline \multicolumn{7}{|l|}{ Eye history } \\
\hline Atopy & $3(1.0)$ & $0(0.0)$ & 0.740 & & & \\
\hline Blepharitis & $3(1.0)$ & $0(0.0)$ & 0.740 & & & \\
\hline Keratitis & $8(2.6)$ & $1(2.7)$ & 0.610 & & & \\
\hline Keratoconus & $8(2.6)$ & $1(2.7)$ & 0.610 & & & \\
\hline Conjunctivitis & $23(7.4)$ & $1(2.7)$ & 0.470 & & & \\
\hline Endophthalmitis & $2(0.6)$ & $0(0.0)$ & 0.510 & & & \\
\hline Congenital glaucoma & $13(4.2)$ & $0(0.0)$ & 0.420 & & & \\
\hline Herpes & $6(2.0)$ & $1(2.7)$ & 0.760 & & & \\
\hline Stye & $2(0.6)$ & $0(0.0)$ & 0.510 & & & \\
\hline Proptosis & $2(0.6)$ & $0(0.0)$ & 0.510 & & & \\
\hline Antimicrobial use & $88(28.5)$ & $18(48.6)$ & 0.020 & 2.50 & $1.19-5.23$ & 0.0100 \\
\hline \multicolumn{7}{|l|}{ Injury } \\
\hline Vegetable & $41(13.2)$ & $0(0.0)$ & 0.040 & & & \\
\hline Mechanical & $15(4.8)$ & $1(2.7)$ & 0.860 & & & \\
\hline Metal & $15(4.8)$ & $3(8.1)$ & 0.650 & & & \\
\hline Chemical burn & $3(1.0)$ & $0(0.0)$ & 0.740 & & & \\
\hline Non-chemical burn & $2(0.6)$ & $3(8.1)$ & 0.004 & 17.29 & $2.40-124.57$ & 0.0050 \\
\hline \multicolumn{7}{|l|}{ Prior eye surgery } \\
\hline Corneal transplantation & $36(11.6)$ & $7(18.9)$ & 0.320 & & & \\
\hline Postoperative complications & $15(4.8)$ & $1(2.7)$ & 0.510 & & & \\
\hline Removal of corneal foreign body & $7(2.3)$ & $1(2.7)$ & 0.680 & & & \\
\hline Suture & $4(1.3)$ & $2(5.4)$ & 0.250 & & & \\
\hline Eyelid correction & $2(0.6)$ & $0(0.0)$ & 0.510 & & & \\
\hline Tumor excision & $2(0.6)$ & $0(0.0)$ & 0.510 & & & \\
\hline Coating & $2(0.6)$ & $0(0.0)$ & 0.510 & & & \\
\hline Blepharorrhaphy & $2(0.6)$ & $0(0.0)$ & 0.510 & & & \\
\hline Antiglaucoma tube insertion & $2(0.6)$ & $0(0.0)$ & 0.510 & & & \\
\hline \multicolumn{7}{|l|}{ Type of contact lenses } \\
\hline Soft & $29(9.4)$ & $7(18.9)$ & 0.130 & & & \\
\hline Rigid & $6(1.9)$ & $0(0.0)$ & 0.850 & & & \\
\hline Therapeutic & $3(1.0)$ & $0(0.0)$ & 0.740 & & & \\
\hline \multicolumn{7}{|l|}{ Comorbidities } \\
\hline Cancer & $7(2.3)$ & $0(0.0)$ & 0.760 & & & \\
\hline Chemo or radiation therapy & $2(0.6)$ & $0(0.0)$ & 0.510 & & & \\
\hline
\end{tabular}

Data are presented as mean \pm standard deviation or $\mathrm{n}(\%)$. 
In univariate analysis that compared patients according to whether the keratitis was caused by Gram-negative or by Gram-positive bacteria, age ( $p=0.01)$ was found to be statistically significant. Indeed, logistic regression showed age (OR 1.06; 95\%Cl 1.01-1.11) to be a risk factor for keratitis caused by Gram-negative bacteria in the (Table 4).

\section{DISCUSSION}

Microbial keratitis and its sequelae are important causes of ocular morbidity and blindness in developing countries. Microbial keratitis is characterized by inflammation of the cornea, usually with stromal infiltration, and is considered an ophthalmic emergency that requires immediate attention. Keratitis can progress rapidly with corneal destruction that causes permanent visual dysfunction.

In the literature, childhood is defined as the period of growth from birth to puberty. However, the definition of the limits of chronological adolescence is controversial. For the World Health Organization, the age is between 10 and 19 years whereas for the United Nations Organization, it is between 15 and 24 years. In Brazil, the Child and Adolescent Statute, law 8.069 of 1990, considers a child to be a person under 12 years old and defines adolescence as the age range $12-18$ years ${ }^{(28)}$.
Childhood keratitis differs from adult keratitis in several respects, including possible reluctance of the child to undergo the clinical examination and sample collection, and the information-gathering regarding triggering factors and inflammation, which is apparently more intense in children ${ }^{(3,15)}$. Among teenagers, contact lenses are becoming increasingly popular as a refractive error correction device, for esthetic reasons. The association between the use of contact lenses and infectious ulcers is well established.

During the period analyzed, $10.1 \%$ of keratitis cases occurred in the age group up to 18 years, mostly among male adolescents. These data corroborate previous studies in which keratitis in children and adolescents accounted for $11 \%$ to $13.1 \%$ of all ophthalmologic visits( ${ }^{(3,8)}$.

Our study found that age, the use of topical antimicrobial drugs, and prior physical burns were associated with fungal and Acanthamoeba spp. keratitis. Age was also associated with keratitis caused by Gram-negative bacteria. As far as we know, no previous study has analyzed this subject.

In our series, the use of topical medication was present in $42.8 \%$ of patients at the time of laboratory evaluation. Other authors have already indicated the use of empirical medication at the time of sample collection in $48 \%$ to $67.1 \%$ of patients with clinical suspicion

Table 4. Univariate and multivariate analyses comparing keratitis caused by Gram-negative bacteria with that caused by Gram-positive bacteria among patients aged from 10 days to 18 years

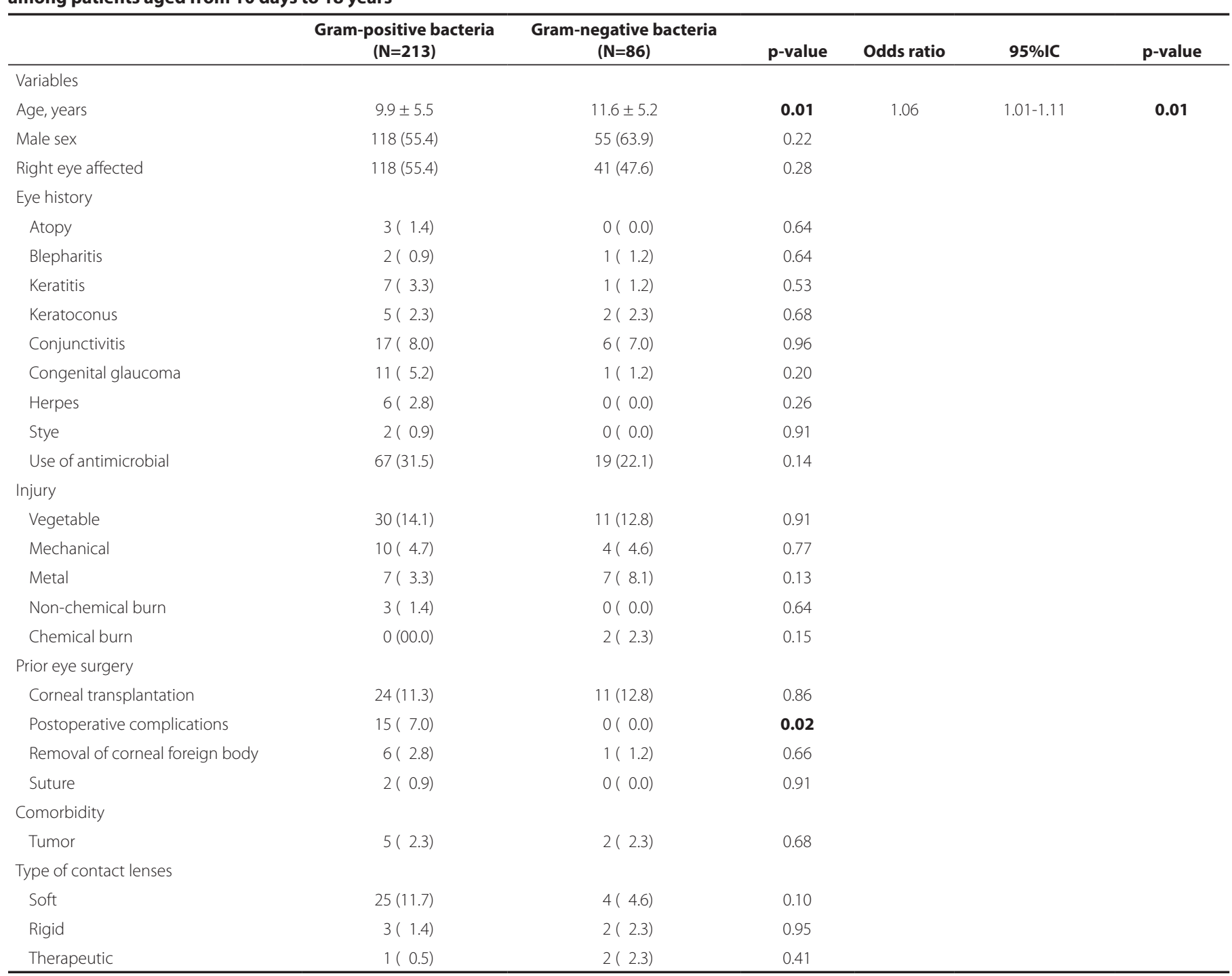

Data are presented as mean \pm standard deviation or $\mathrm{n}(\%)$. 
of keratitis $(3,9,16)$. As they are already widespread, the use of antibiotics can inhibit bacterial growth, favoring the appearance of other microorganisms. This factor was statistically significant in the group of patients with non-bacterial keratitis and may be considered as a predisposing factor.

A history of trauma was the most common antecedent found in our study as cause of keratitis in the age range studied, affecting $33.5 \%$ of patients. Trauma has been reported as the major risk factor for keratitis in several published studies, accounting for $21.2 \%$ to $58.8 \%$ of $\operatorname{cases}^{(8-18,29)}$.

In our study, $18.2 \%$ of patients had a history of using contact lenses. Soft lenses were the most commonly used type. More than $90 \%$ of patients with a positive culture for Acanthamoeba spp. were contact lens users and all were adolescents. As has been said, the association between the use of contact lenses and infectious ulcers is well established. Several authors have reported the use of contact lenses, especially orthokeratology, as a predisposing factor for keratitis in children and adolescents $(3,8-10,14,17,19,20,30)$. The use of this type of lens is not common in Brazil.

Comorbidities were present in $5.8 \%$ of the study patients; this was lower than rates reported in previous studies ${ }^{(3,8-14)}$. Cancer was the main comorbidity, present in $2 \%$ of our records. This percentage was lower than the rate of 3.8\% reported by Onakpoya et al.(11). Other ocular antecedents found in our study have been reported by several authors, citing similar percentages $s^{(3,10,11,19)}$

The prevalence of microorganisms responsible for microbial keratitis in children and adolescents varies in different regions of the world(3). Microbial cultures were positive in $40.3 \%$ of the study sample, whereas in the literature positivity has ranged from $33 \%$ to $87 \%(3,8-10,12-18,20,29)$. Polymicrobial isolates accounted for $9.5 \%$ of positive cultures in our study. In previous studies, the positivity of polymicrobial cultures has varied from $6.9 \%$ to $27 \%{ }^{(3,8-10,12,14)}$. As observed in other studies, the inherent difficulty in getting corneal samples from patients, the use of antimicrobials, improper corneal sampling, and microorganisms with slow growth on culture media may account for the low positivity rate observed in our study ${ }^{(3,15)}$.

The presence of Gram-positive bacteria in keratitis in this study was $71.8 \%$, similar to the level previously reported elsewhere $(3,8,9,12-17,19,20,29)$.

Of the identified etiologic agents, the most common was coagulase-negative Staphylococcus, which was isolated from 23.8\% patients; this was followed by Staphylococcus aureus (20.9\%) and Pseudomonas spp. (14.2\%). These results were similar to those observed in the elderly population in a previous study conducted in our institution ${ }^{(2)}$.

Methicillin-resistant Staphylococcus spp. showed a trend of resistance to most antimicrobials, something that has also been observed by other authors ${ }^{(15,19,20,29)}$, whereas coagulase-negative Staphylococcus, Streptococcus spp., and enterobacteria showed good susceptibility to the majority of antimicrobial drugs tested. Streptococcus pneumoniae strains showed no resistance to penicillin. Pseudomonas aeruginosa strains showed no resistance to ciprofloxacin and low resistance to polymyxin B, gentamicin, and tobramycin, in contrast to the study by Moreno-Andrade et al., who reported $100 \%$ resistance to this antimicrobial(29).

The positivity of fungal infection among children and adolescents was $4 \%$ in our study, whereas the positivity for fungal infection in previously published studies has ranged from $4 \%$ to $48.7 \%(3,8-10,12-14,16,17,19)$. Fusarium solani complex was the most commonly isolated fungus, as was the case in other previous studies $(3,10,17)$.

Keratitis caused by the protozoan Acanthamoeba spp. showed $6.6 \%$ positivity in the present study, which again is similar to previous studies $(3,9,12,19)$. It is noteworthy that all patients with positive culture for Acanthamoeba spp. were adolescents and that 91.3\% had a history of using contact lenses. It is likely that increasing the frequency of use of contact lenses by teenagers increases the risk of adolescents developing corneal ulcers by Acanthamoeba spp.

In conclusion, we found that the risk factors for infectious keratitis in children and adolescents were noticeably the same as those observed in adults. We found that age, the use of antimicrobials, and injuries from physical burns were predisposing factors for non-bacterial keratitis. Age was associated with Gram-negative keratitis.

\section{ACKNOWLEDGMENTS}

The authors thank Prof Dr Annette Silva Foronda for her contribution on identifying the Acanthamoeba spp. positive cultures.

\section{REFERENCES}

1. Whitcher JP, Srinivasan M. Corneal ulceration in the developing world-a silent epidemic. Br J Ophthalmol. 1997;81(8):622-3.

2. Passos RM, Cariello AJ, Yu MC, Hofling-Lima AL. Microbial keratitis in the elderly: a 32-year review. Arq Bras Oftalmol. 2010; 73(4):315-9.

3. Hsiao CH, Yeung L, Ma DH, Chen YF, Lin HC, Tan HY, et al. Pediatric microbial keratitis in Taiwanese children: a review of hospital cases. Arch Ophthalmol. 2007;125(5):603-9.

4. World Health Oorganization (WHO). Global data on visual impairments 2010. Geneve: World Health Organization; 2012.

5. Sofi RA, Wani JS, Keng MQ. Profile of children with ocular trauma. JK-Practitioner. 2014; 17(1-3):44-50.

6. Serrano JC, Chalela P, Arias JD. Epidemiology of childhood ocular trauma in a northeastern Colombian region. Arch Ophthalmol. 2003;121(10):1439-45.

7. Sociedade Brasileira de Pediatria (SBP). Problemas oftalmológicos mais frequentes em pediatria [Internet]. São Paulo: SBP; 2013. [citado 2013 Fev 7]. Disponivel em: www.intranet.sbp.com.br.

8. Ormerod LD, Murphree AL, Gomez DS, Schanzlin DJ, Smith RE. Microbial keratitis in children Ophthalmology. 1986;93(4):449-55

9. Clinch TE, Palmon FE, Robinson MJ, Cohen EJ, Barron BA, Laibson PR. Microbial keratitis in children. Am J Ophthalmol. 1994;117(1):65-71.

10. Cruz OA, Sabir SM, Capo H, Alfonso EC. Microbial keratitis in childhood. Ophthalmology. 1993;100(2):192-6.

11. Onakpoya $\mathrm{OH}$, Adeoye $\mathrm{AO}$. Childhood eye diseases in southwestern Nigeria: a tertiary hospital study. Clinics. 2009;64(10):947-52

12. Kunimoto DY, Sharma S, Reddy MK, Gopinathan U, Jyothi J, Miller D, et al. Microbial keratitis in children Ophthalmology. 1998;105(2):252-7.

13. Vajpayee RB, Ray M, Panda A, Sharma N, Taylor HR, Murthy GV, et al. Risk factors for pediatric presumed microbial keratitis: a case-control study. Cornea. 1999;18(5):565-9.

14. Al Otaibi AG, Allam K, Damri AJ, Shamri AA, Kalantan H, Mousa A. Childhood microbial keratitis. Oman J Ophthalmol. 2012;5(1):28-31.

15. Chirinos-Saldaña P, Lucio VMB, Hernandez-Camarena J, Navas A, Ramirez-Miranda A, Vizuet-Garcia L, et al. Clinical and microbiological profile of infectious keratitis in children. BMC Ophthalmology. 2013;13(54):1-6.

16. Maidana E, Gonzalez R, Melo Junior LA, Souza LB. [Infectious keratitis in children: an epidemiological and microbiological study in a university hospital in Asuncion-Paraguay]. Arq Bras Oftalmol. 2005;68(6):828-32. Portuguese.

17. Song $X$, Xu L, Sun S, Zhao J, Xie L. Pediatric microbial keratitis: a tertiary hospital study. Eur J Ophthalmol. 2012;22(2):136-41.

18. Tabbara KF, Badr IA. Changing pattern of childhood blindness in Saudi Arabia. Br J Ophthalmol. 1985;69(4):312-5.

19. Wong VW, Lai TY, Chi SC, Lam DS. Pediatric ocular surface infections: a 5-year review of demographics, clinical features, risk factors, microbiological results, and treatment. Cornea. 2011;30(9):995-1002.

20. Hong J, Chen J, Sun X, Deng SX, Chen L, Gong L. Paediatric bacterial keratitis cases in Shangai: microbiological, profile, antibiotic susceptibility and visual outcomes. Eye (Lond). 2012;26(12):1571-8.

21. Parmar P, Salman A, Kalavathy CM, Kaliamurthy J, Thomas PA, Jesudasan CA. Microbial keratitis at extremes of age. Cornea. 2006;25(2):153-8.

22. Tabbara KF, Hyndiuk RA, editors. Infections of the eye. 2nd ed. Boston: Little Brown; 1996.

23. Höfling-Lima AL, Moeller CT, Freitas D, Martins EN. Manual de condutas em oftalmologia. São Paulo: Atheneu; 2008.

24. Foronda AS. Observações sobre amebas de vida livre potencialmente patogênicas [tese]. São Paulo: Universidade de São Paulo; 1979.

25. Nosé W, Sato EH, Freitas D, Ribeiro MP, Foronda AS, Kwittko S, et al. Úlcera de córnea por Acanthamoeba: quatro primeiros casos no Brasil. Arq Bras Oftalmol. 1988;51:223-6.

26. Koneman EW, Allen SD, Janda WM, Schreckenberger PC, Winn Jr WC. Color Atlas and textbook of diagnostic microbiology. 5th ed. Philadelphia, New York: Lippincott; 1997.

27. Software MS. MedCalc 11.6.1. Belgica 1993 - 20131993 [cited 2013 02/07Feb 7]. Available from: www.medcalc.org/.

28. Einsenstein E. Adolescência: definições, conceitos e critérios. Adolesc Saúde. 2005; 2(2):6-7.

29. Moreno-Andrade A, Ramirez-Miranda AJ, Navas A, Hernandez-Camarena JC, Vizuet-García L, Gaona-Juárez C, et al. Clinical and microbiological profile of infectious keratitis in children. Seattle (USA): ARVO; 2013.

30. Young AL, Leung KS, Tsim N, Hui M, Jhanji V. Risk factors, microbiological profile, and treatment outcomes of pediatric microbial keratitis in a tertiary care hospital in Hong Kong. Am J Ophthalmol. 2013:156(5):1040-4. 